\title{
The SWOT Analysis and Strategy Research on the Integration Development of Campus News Media
}

\author{
Yao Huang ${ }^{1}$, Hui Pan ${ }^{2}$, Ruixiang $\mathrm{Ou}^{2}$ \\ ${ }^{1}$ Propaganda Department of Party Committee, Southern Medical University, Guangzhou 510515, \\ China \\ ${ }^{2}$ Library of South China University of Technology, Guangzhou, 510640, China
}

Keywords: Campus media; Media integration; SWOT analysis; Strategy research

\begin{abstract}
The campus media in our country has become the transmission leader of the university culture presently. In the face of the present complicated media ecology environment, it is urge for our campus to develop media integration. Based on the SWOT analysis, the advantages and disadvantages of present integration development of campus news media are analyzed, and the opportunities and challenges of the media integration development are discussed. Finally, the strategies and suggestions on the integration development of campus news media are derived with the SWOT analysis results.
\end{abstract}

\section{Introduction}

The rapid development of higher education in our country makes the campus media invigorating. However, the media ecology environment is complex and it is urgent for the campus media to make the further development through the media integration. Based on the present campus media ecological environment, this study analyzes the basic conditions for the integration of campus media in our country, and the factors influencing the integration of campus media from the aspects of advantages and disadvantages, opportunities and challenges with the SWOT analysis method.

\section{The advantages of the campus media integration}

The Spread Field Stability Campus communication field has the advantage of propagation time stability and location fixation. In the campus communication field, the location of the spread and space immobilization are beneficial for the campus media to carry out communication activities in the same and controllable space to, while react on the spread and integration of the campus media to form a fixed and stable viscous audience. In addition, it is convenient for the college students to make interpersonal communication to achieve the oral spreading. The stability of the campus spread field can be helpful for the campus media to open the spread market quickly and build a stable spreading space, which can form a long-term, fixed and trusty college students audience and increase the user viscosity.

The spreading content fixity. The fixity of our campus media content production promotes the content integration among the campus media organizations. In the face of the same campus information content, different campus media organizations can adopt and learn from each other to acheive the content sharing, to establish the campus media content production chain eventually, in order to save the campus media content production resources and achieve the fast implementation of the scale production mode, which lays a solid foundation for the integration of campus media development in our country.

\section{The disadvantages of the campus media integration}

The deficiencies in administrative management system There are some deficiencies existing in our country's campus administrative departments management of the campus media, such as the multi-sectoral management, unstandardized management regulations, unsound review and so on, 
which influence the role of campus communicator taken by the campus media. To promote our campus media integarion, colleges should improve the management mechanism of campus media, organize the integration from management perspective, establish the multi-functional integration management mechanism, and apply a unified system management pattern to each campus media organization.

The shortage of working capital At the present stage, due to the tightening of the management system and the strict restriction of the university's commercial access, the funding source of our campus media mainly depends on the financial input of the university administration, and this single funding source has a direct impact on the development of campus media. The rapid change of the new media environment has a direct impact on the production and operation of our campus media. The material basis of the campus media cannot meet the funds requirements of the rapidly changing new media, which makes the campus media lack the fundamental motivation in the platform development and technological innovation.

Versatile human resources deficiency. At present, most college campus media practitioners are college students, whose major are usually not the journalism or communication sciences. The polarization and disconnection between the our campus media staff and part-time student journalists have a direct impact on the campus media product integration.

The Talent is the core guarantee of the media product innovation and organizational development, and the establishment of a campus media team with the comprehensive media capacity can solve the problem of versatile campus media human resources deficiency.

Media platform hysteresis. Due to limiting factors such as the funds shortage and the human resources shortage, the development of our campus media platform is sluggish. For example, the platform hardware and the software core technology are behindhand, which affects the operation of campus media platform.

\section{Opportunities for the campus media integration}

The time opportunity. According to statistics: up to the December 2016, the scale of China's Internet users has reached to 731 million, and the Internet penetration rate has reached to 53.2\%.The prosperity of Internet industry invigorates the upgrade of media platform: the advanced technology in the Internet era promotes the optimization and upgrades of the media channels and platforms, and the media platforms become more convenient, intensive and massive. The media industry has ushered in a new development opportunity.In 2015, the state proposed to build a campus network alliance, and helped colleges to make new progress in propaganda work by the policy support. Under the time opportunity of technological innovation in the Internet industry and the great importance to the propaganda work, what provides a healthy, stable and harmonious external development environment for our campus media integration development.

Industry opportunities The technological innovation in communications, computer science and the network development develop a broader media carrier and platform for the media industry. The progress of the Internet makes the public obtain information more convenient, fast and effective, and meet the public requirements of receiving information in-time. The innovation in mobile phone network makes the massive and customizable information swarm into the public information world, and the technological progress creates the opportunities for the media industry to achieve the integration. The global integration of our media industry makes all aspects of campus media are subject to the impact of social media, and the present campus media market has been the important way for the social media to open up media resources and improve the brand value.

Academic opportunities. In the process of campus curriculum reform and training plan adjustment, the relevant subjects media are also expericing subtle changes. Many colleges combine the spreading theory and the new media technology to develop the cross-teaching training model, and more professional teachers focus on the research in new media technology and media integration. The college journals, television columns, mobile platforms and other campus media organizations founded by the relevant media majors provide academic theory, human resources, practical 
operational platform for the development of the campus media, which help the students to apply the theoretical knowledge in practice quickly, and improve the campus media part-time student journalist's manipulative ability. The pretty academic atmosphere of discipline construction and subject practice in our campus can be helpful to improve the media literacy of the campus media journalists, supplement the campus media human resources, and reserve talents for our campus media integration.

\section{Challenges for the campus media integration}

Internal challenges. The integrated development of the media requires the media institutions to have a professional, systematic organizational human planning and resources. The biggest internal challenge for our campus media integration is the human resources reserve, and the specific performance is the lack of guidance teachers and the loss of part-time student journalists.

The lack of guidance teachers: the current campus propaganda work is complex, and the instructors not only need to complete theown works, but also need to spend extra time and energy to manage the campus media. As a result, the instructors are often powerless, which would affect the progress of the campus media. Compared to the U.S campus media instructors that are mainly the journalism professional teachers with expertise and continuity, our campus media instructor's professional level is weak and practical experience is less, which affects specialization development of campus media.

The loss of part-time student journalists: Due to the restrictions of the training mechanism of campus media talents in our country, the phenomenon of human resource fault is serious. It usually costs 1 year to train a qualified campus media part-time student journalist, however, the students are usually facing the graduation and leave the organization at just to be able to independently made, complete the interview task, which directly affects the campus media training system and results in the slow campus media echelon hatching and human resources loss. The lack of our campus media human resources leads directly to the decline of overall business capacity of campus media organizations, affecting the integration of campus media.

External challenges. In the digital era, the popularity of Internet technology and the development of modern communication technology have changed the spreading mode and spreading pattern in the campus. In the process of our campus media integration, the biggest external challenge is the reduction and loss of college students' audience.

Traditional campus media cannot keep up with the new trend. Due to the long spreading cycle and the single and fixed spreading ways, the traditional campus media has lost the original and fixed audience. Many of the campus new media similar products, similar platform to carry out homogeneous competition, scattered, lost the campus audience, and cause duplication of information content, lost the quality of content, leading to the weakening of its dissemination of authority.

With the rapid development of the media industry, the college students' personal spreading space and pattern continue to expand. College students have more channels and wider ways to obtain diversified information. Massive and fragmented messages occupy the media space and time of college students quickly. College students pay the time and energy to read the content produced by the social media, and naturally reduce the frequency of concerning about the information generated by the campus media.

The SWOT Analysis of the Campus News Media Integration development. Based on the full consideration of the internal and external resources, the SWOT analysis summarizes the advantages and disadvantages, opportunities and challenges of the campus news media integration, which are performed in the form of designed matrix in advance. Then the systematic analysis is performed to match the interrelated parts in the four parts to develop a solution strategy. The overall SWOT analysis of the campus news media integration is presented as Table.1 
Table. 1 The SWOT analysis of the campus news media integration

\begin{tabular}{|c|c|c|}
\hline & Advantages & Disadvantages \\
\hline Internal enviroment & $\begin{array}{l}\text { (1) The Spread Field } \\
\text { Stability } \\
\text { (2) The Spread Field } \\
\text { Stability }\end{array}$ & $\begin{array}{l}\text { ( } 1 \text { ) The deficiencies in } \\
\text { administrative management } \\
\text { system } \\
\text { (2) The shortage of working } \\
\text { capital } \\
\text { (3) Versatile human resources } \\
\text { deficiency } \\
\text { (4) Media platform hysteresis }\end{array}$ \\
\hline Opportunities & SO & WO \\
\hline $\begin{array}{l}\text { (1) the time opportunity } \\
\text { (2) Industry opportunities } \\
\text { (3) Academic opportunities }\end{array}$ & $\begin{array}{ll}\text { Campus } & \text { media } \\
\text { conglomeration } & \end{array}$ & $\begin{array}{l}\text { human resources optimization } \\
\text { training }\end{array}$ \\
\hline Challenges & ST & WT \\
\hline $\begin{array}{l}\text { (1) The lack of guidance } \\
\text { teachers } \\
\text { ( } 2 \text { ) The loss of college } \\
\text { students } \\
\text { ( } 3 \text { ) The loss of college } \\
\text { students audience }\end{array}$ & $\begin{array}{l}\text { Sharing campus contents } \\
\text { and resources }\end{array}$ & $\begin{array}{l}\text { Developing demassified } \\
\text { communication }\end{array}$ \\
\hline
\end{tabular}

\section{Strategies and Suggestions on the Development of Campus News Media}

Campus media conglomeration Media organization conglomeration has many advantages such as clear organizational structure, efficient communication activities, high input-output ratio, which can improve the information arrival rate and attract more audience attention. The media organization conglomeration has became the outstanding case for the campus media. Driven by the social media conglomeration, our campus media is also in the development direction of campus media conglomeration, which provides the referential successful experience for our campus media integration.

Campus media should analyze the staff, and the existing rules and regulations to form the organization's management analysis report;

According to the organization and management analysis report, and management (guidance) teachers, members of the organization, other campus media practitioners to carry out exchanges and discussions to human resources management, standardize the rules and regulations as the key content, and ultimately form in line with their own media development management regulations and systems.

In the process of integration of the organization, the implementation of accountability, to promote the campus media responsible person to actively find and find the organization's problems, and immediately notify the relevant departments to discuss and make appropriate adjustments. The establishment of members of communication, feedback system, build communication platform to e-mail, WeChat, etc. to collect members of the views and suggestions to promote the healthy development of the organization.

Human Resource Optimization Training The development of human training management norms, to their own media types, different positions for the category, purpose, targeted to carry out various forms of regular, colorful training, practical activities, enhance the integration of organizational development and support.

Cooperate with other campus media organizations to build interactive platform, complement each other, win-win cooperation, promote communication between the media on campus, enhance campus media communication, and lay a good foundation for campus media integration The 
To organize campus media activities, and actively organize members to participate in other campus media organizations practice.

Share content within the school. Campus media organizations should work together to share resources, play a multi-channel, multi-form, multi-mode cooperation model, intensive, integrated campus content resources, mutual support, expand the impact of cooperation and win-win situation.According to the different contents of communication, the content of campus communication in our country can be divided into campus daily news, campus news, campus activity information, campus characters interviews, campus special reports and other types. Each campus media should be based on the type of content dissemination, based on their own media advantages, to carry out reporting activities. Through the establishment of content sharing program, build a shared resource library, carry out the integration of the contents of the school, etc., to achieve the effective sharing of campus media content resources.

Developing demassified communication. China's campus media organizations need to change the traditional concept of communication, to take the initiative and consciously explore what information students need information, like to use what media platform, "service students, close to the students" concept of campus communication activities.

Campus media should change the previous mode of operation, to determine the differentiation, the focus of the communication strategy, according to the content production, set up communication channels, expand the business model. Campus media should focus on the psychological variables and behavior variables of college students, combined with the age, gender and professional characteristics of college students, and carry out operational activities for the specific differences of college students.

\section{Acknowledgements}

This paper is the result of Jointly-Funded Project of Philosophy and Social Sciences of the 13th Fifth-year Plan of Guangdong Province in 2016 named "Research on the Integration Development and Innovation of Campus News Media” (Grant No. GD16XXW03 ).

\section{References}

[1] Lu W. On Theoretical Integration of New Media with United Front in Colleges [J]. Journal of Liaoning Medical University (Social Science Edition), 2014, 1: 041.

[2] XIAN K, YANG X. Research into the Integration of Socialist Core Values into Teaching System of College Education_- In the View of New Media [J]. Journal of Liaoning Normal University (Social Science Edition), 2014, 5: 016.

[3] Rong S. New Media Service of Digital Library under the Background of Triple Integration [J]. Journal of Library and Information Sciences in Agriculture, 2013, 1: 048.

[4] Wenzel M. Media Effects on Support for European Integration in Old and New EU Member States [J]. Polish Sociological Review, 2015 (2 (190)): 153-169. 